\title{
The Curse of the Place: A Post-Colonial Study of O'casey's Dublin's Trilogy
}

\author{
Amal Riyadh Kitishat \\ Associate professor in English Literature-Al Balqa Applied university -Ajloun University College. \\ Department of English Language and Literature- Jordan \\ kitishat@gmail.com
}

\section{Muneerah Badr Almahasheer}

Assistant professor in English literature - Imam Abdulrahman Bin Faisal University -Faculty of ArtsDept. of English Language. KSA

mbalmahasheer@iau. edu.sa

\begin{abstract}
Sean O'Casey is considered one of the greatest play writers in the Irish Dramatic Movement. His importance refers back to his realistic portrayal of the Irish society in general and of Dublin in particular. It is his experience in the slums of Dublin that provides him with the details that he employed in his plays. The study aims at proving that by describing Dublin slums, O'Casey indirectly directs a criticism of the social and political reality as a background of the bloody events that Ireland witnessed. The plays that are going to be studied are The shadow of a gunman, Juno and the Paycock, Red Roses for me. Unlike other Irish dramatists who idealized Ireland, O'Casey reveals the contradictions in the Irish society. Thus, the study concludes that O'Casey is distinguished from other Irish writers in avoiding the idealized portrayal of Ireland and offers us a mock-heroic treatment of his society
\end{abstract}

Keywords: O’Casey; Mock-heroism; Dublin city; Dublin's Trilogy .post -colonial literature, Irish drama.

\section{Introduction}

Probably more than any Irish dramatist, the figure of Sean O'Casey is still considered to be the greatest among those who benefited the Irish Dramatic Movement. Sean O'Casey is the thirteenth child of Michael Casey a descent from a protestant famous family in Ireland. However; it was when O'Casey was eight years old when his father died, leaving the family facing Poverty in Dublin slums. Actually his experience in the Dublin Slums was of a great impact on his dramatic occupation since it provided him with the social background for most of his Plays. However, he taught himself to read and write at home Because of an eye-disease that prevented him from studying at School. (Stanley1984, 6)

Though he is a descendent from a religious family, he gives up Christianity and adopts Communism as his ideology.

In his twenties, O'Casey becomes politically active and joins the Irish labour party in a search of new values. Since his active rule in the Irish politics, he becomes the secretary of the Irish Citizen Army. This army was made for self-defense O'Casey also took Part in the Easter Rebellion of 1916. But he withdrew because of his disappointment in the absence of positive constructive action in the Citizen Army.(ibid )His first literary achievement was the publishing of stories about his political experience. This book was entitled as The Story of the Irish Citizen Army. Realizing 
the success his book had, he involves seriously in writing plays. He started writing Plays to the Abbey Theater. The Abbey directors at that time W.B Yeats and Lady Gregory write him letters encouraging him to go on in his play-writing

\section{$2 \quad$ O'Casey's Dublin Trilogy between Realism and Naturalism}

O'Casey's achievement for the drama is characterized by a shift in the employment of Irish themes from that sentimental portrayal of Ireland as a "sacred country" into realistic satirist mode in writing. Consequently his works include a social and political criticism of the urgent and social problems that are found in the Irish society. To be specific, O'Casey takes his social problems in his considerations while writing his plays. We have the drunkard, the hypocrites, and the false nationalists as heroes for the majority of his works. So, he offers us the mock heroic characters in a society that is characterized by the heroic myth that the Irish society pretends to have. Actually, it is the Irish society that O'Casey is mocking for providing heroes with such negative qualities. He also tends to mock false pretentious heroic deeds by revealing the hidden real face of those hypocrite heroes. His vision of life is tragic and ironic. He introduces the suffering of the ordinary Irish people during the time of the World War. O'Casey involvement in politics is reflected in his works. Bernice Schrank points to O'Casey political ideas. He considers O'Casey as one of the first modern dramatists who engages "proletarian character in serious (even tragic) actions. ( Schrank 1974, 43 )

By introducing these themes in to Irish drama, in addition to the realism he inherits from his predecessors, For example, Kitishat (2012)in "Colonialism and the recreation of identity: The Irish Theatre as case study." draws the attention to the fact that Irish culture is identical from other European counterparts because of the dramatists' treatment which depends on the " adoption "and the " reintroduction of the Irish habitat "(83).Therefore, a new phase of the Irish dramatic movement established itself. O'Casey seems to differ from other dramatists in his rare way of writing. His method can be seen as "clear cut and satiric".(Fremor ;1977,2017) His comic satire points directly to a tragic implications. The tragic and comic plays are integrated together so that his plays can have great effect.

His attitude to comedy is totally different from his predecessors. He provokes a rebellious laughter or as Grene called the "antic laughter ".(Grene ; 1985 , 41). The comic character must mock his society by undermining the sacred values which the oppressive world had on individuals. O'Casey defines the laughter as a "great natural stimulator, a push full entry into life, and once we can laugh, we can live". (O'Casey; 1956, 226).

There is no doubt that his approach is peculiar since his treatment of Irish slum life is new in the twentieth century drama. Actually very few dramatists have introduced realistically the life and problems of the people of the slums. Therefore, his experience in Dublin slums enriches his dramatic works. In other words, his realistic depiction of the Dublin slums life is introduced without sentiment or prejudice.(Fremor ;197). He honestly introduces what he has experienced in Dublin slums after his father's death. His works include a bitter social criticism which results in the audience rejection of his play and accuses him of insulting the Irish national and religious characters. For example Daniel, reports the audience attitude toward O'Casey's plays:

To sit among the audience in the Abbey theater when one of Sean O'Casey's plays is on the Stage, is to learn how true it is that single plot is, with great gaiety, attributed to the whole people. To remain silent in the midst of that noisey gaiety, even to fling brickbats about, protesting against it , is one thinks, to avoid the deeper vulgarity ... Religion and nationality are not separable in Ireland (cookery;1931,181)

Therefore, it is apparent that both of Synge and O'Casey are similar with regard to the reaction of people toward their dramatic works. In fact, O'Casey continues to suffer from the expected hostility from the Catholic Church in Ireland and America. Simmons discusses the religious disapproval of 
O'Casey plays. He assures us that the Catholic Church declares Within the Gates to be "Unspeakable filth".(Simmons; 1988,23). He also states the fact that in 1930 the film of Juno and the Paycock was burned in the streets of Limerick. Also, The production of The Drums of Father Ned "was cancelled in 1958 when the Dublin Tostal committee gave in to pressure from Archbishop Mc Quade".(Ibid).It is obvious then that the Catholic hierarchy, as Maxwell says, attacks him because he refuses to "pay even lip service to the stereotyped image of national piety".(Maxwell 1991 ,xv). Still, he doesn't hesitate in depicting the real circumstances of his society. O'Casey always asserts the need of a drama treats serious problems of his society.

\section{A political and a social Perspective of Dublin Slums}

The social and political perspective is one of the significant dimensions which o'Ceasy focused on in the presentation of Dublin City. In The shadow of a Gunman (1923), O'Casey succeeds in offering the Abbey an important play whose immediate fame saves the Abbey from collapse. Actually, the Abbey faces a problem which was concerned with the lack of distinguished plays to be acted on its stage. This is due to the earlier death of Synge which created a gap that was not filled except by the appearance of Sean O'Casey. This situation caused financial troubles for the Abbey, and therefore, the Abbey directors were looking for new dramatists who can help them in avoiding bankruptcy. O'Casey Dublin trilogy: The Shadow of a Gun man, Juno and The Paycock, Plough and the Stars save the Abbey from its serious situation. They also help O'Casey to improve his own life. (Darin 13)

The Shadow of Gunman is tragedy in two acts. The play is set in the Slums of Dublin during a critical period of time in the history of Ireland. This play introduces the life of the Irish citizens during the Anglo-Irish war that followed the Easter Rising of 1916.

O'Casey is different from other Irish writers such as Yeats, in his ironic attitude to patriotic heroes and heroines. In fact, in his earlier works, the Dublin trilogy, he expresses the conflict that Ireland has lived between the dead and actuality. (Ayling1991,xv) Actually, the author's disillusionment with the Irish political situation is apparent. The play was performed during the application of the Anglo-Irish Treaty. (Maroldo 1983, 18) therefore, O'Casey is trying to give a picture of his society during the terrible Anglo-Irish war.

Unlike Yeats who focuses his plays on hat magnificent heroic aspect of the Irish life, O'Casey introduces the suffering of the Dublin workers in his works. O'Casey engages" the proletarian characters in serious (even tragic) action."(Schrank1997,43). It is this class of people that O'Casey cares about and this is the source of his greatness. He wants his audience to know what kind of life poor Dubliners have lived during the time of war.

If we take the political and the social background of the play, the interpretation of the play will be more significant. The plot of the play revolves around one character, Donal Daveron, this false assumption, that Daveron is patriot, was accepted by the poet because it benefits him in many ways: he becomes the admiration of people and beautiful girls in particular. In the second act, action begins to develop violently. One of Daveron's friends left in Daveron's room a bag of mills bombs. Because of Daveron's false reputation as an IRA gunman, the British soldiers come to search his room. It is at the moment that Daveron discovers the hidden bag of bombs. During this crisis, one of Daveron's admirers, Minnie comes to help him. It is this episode that reveals Daveron's real shaken identity. To get rid of the bombs, he lets Minnie take them into her room. He does so because he thinks that the soldiers will not search a girl's room. However, she was arrested and eventually killed. In the last act of the play, we can see the hidden identity of he "hero". The hero is proved to be a coward and defeated man. he is a "Shadow" of gunman. His false reputation as a gunman has destructive consequences on him; he lost his girl friend, and his self respect.

O'Casey's introduces the suffering of the individual under disapproving of war. This image is totally different from the earlier phase of the Irish Dramatic Movement in which Yeats and his followers present the Irish man as a man who has a great national patriotic sense. Hence, there is a 
complete shift in the treatment of the Irish themes which begins by Synge and is shaped in its final appearance in the works of O'Casey.

O'Casey's drawing upon the Irish themes is for ironic and satiric effect. By mocking the major characters in the play, Daveron and Seumas, he expresses his skeptical attitude toward war in general. He was against the use of violence to liberate Ireland; (Maxwell, 102) this fact explains his political disappointment is the cause behind his mocking of the heroes. In this play, Daveron is revealed to be an ordinary man without any heroic characteristic. The only character that has a definite and a clear-cut political creed is Maguire, who has left the bombs' bag in Daverone and Seumas's room.

It is clearly realized that O'Casey's method of characterization tends to introduce the hero as a victim of his social, economic and religious limitation (Maroldo, 98). Daveron is coward whereas Minnie is brave but she is naïve. Seumas shields, the man who shares the room with Daveron, is a peddler who was once involved in the national movement but he withdrew and developed a cynical attitude toward the national movement. Maroldo points to the similarity between Daveron and Seumas by arguing that they complete each other. He even attracts our attention to the assumption that there is similarly between Seumas and O'Casey's personality. (ibid,100). However, with regard to this critical opinion, it is worth noting that the majority of the political criticism is introduced by the character of Seumas shields. His speech includes somewhat of the O'Casey has declared to be a false nationalism. Consequently, it is suitable in this context to provide the following paragraph to note how far is O'Casey critical of the exaggerated idealization of the country.

Seumas. [With a gesture of despair]. Oh, this is a hopeless country! There's a fellow [Maguire] that thinks that the four cardinal virtues are not found outside the Irish Republic.I don't want to boast about myself. I could call myself as good as Goal as some of those that are knocking about now-but I remember the time when I taught Irish six nights a week, when in the Irish Republican Brotherhood I paid my rifle levy like a man, an' when the church refused to have anything do with James Stephens, I turned a prayer for the repose of his soul for dark Rosaleen, the only answer you can get from a roarin' Republican to a simple question is

O' Casey criticized violence which becomes an ordinary feature in the Irish daily life. He directs his speech to the Dublin audience since they are involved in this subject.

Another subject that $\mathrm{O}^{\prime}$ Casey focuses on is hypocrisy. This theme is represented in the play in many different dramatic episodes. The first hypocrite character is Daveron who pretends to be a gunman. Though he is aware of the people's serious thinking of him as a hero, he doesn't reveal his real identity. On the contrary he seems to enjoy this image which consequently causes him to lose selfrespect. Also, he always keeps reporting Shelly's lone, "the poet ever strives to save the people" but, as it is clearly shown in the play, he refuses to save anyone even Minnie who tries to help him.

Furthermore, O'Casey's satirical way of writing becomes bitter when he suspects the Irish ability in managing Ireland's own affairs. He even mocks their dealing with things in a wrong way:

Seumas: that's the Irish people all over they treat a joke as a serious thing and a serious thing as a joke. Upon me Soul, I'm beginning to believe that the Irish people aren't, never were, an' never will be fit for self-government. They've made Balor of the Evil Envy king of Ireland, an' so sign on it ther's neither conscience nor honesty from one end of the country to the other. (Act. 1, p. 7 )

There is no need to wonder then why the people of Dublin as well as Ireland attack his plays. There is some kind of insult embedded in his last speech which is quoted above. O'Casey accuses his country people of lacking the serious sense of responsibility with regard to their political attitude toward their country. 
Yet, O'Casey mocks the image Cathleen Ni Houlihan, the symbol of Ireland oppressed and rich in hope. His mockery of Cathleen ni Houlihan is due to the fact that it was invoked by a mock heroic character like seumas. Also she was mocked in the context by which she was introduced.

Seumas: What's the use of having anything packed and ready when he [Maguire] didn't Come ! No wonder this unfortunate country is as it is, for you can't depend upon the world of single individual in it ... oh Kathleen in Houlihan, your way's a thorny way. (Act.1, p. 10).

He accuses Ireland represented in the character of Cathleen of being full of troubles that cause difficulties for its people! However, this ironic touch with regard to the treatment of the political matters of the Irish society has reached its highest point when both of Davoren and Shields denies their Irish names and identity when they are asked by an Auxiliary of the English forces:

The Auxiliary. What's your name?

Davoren : Davoren, Dan Davoren; sir.

The Auxiliary. You're not Irishman, are you?

Davoren. I-I-I was born in Ireland.

The Auxiliary. Ow, you were, were you, Irish han'

proud of it, ay?

[to seumas]. What's your name?

Seumas: seums--- Jimmie Shields, sir.

(Act. II, p. 38-39).

In this final episode we had a new image of Irishmen who denied their real Irish identity. Indeed, they pretended to have English names. These characters were hypocrites, cowards, lacking courage and without any identity. O'Casey introduced the tragic-comic treatment of Irish problems. He was able at least in his first plays to make Irish people laugh at their follies represented in the characters of Seumas and Davoren.

\section{$4 \quad$ An Economic Perspective of Dublin Slums}

O'Casey second Dublin trilogy play is Juno and The Paycock; actually, it is this play that makes him famous. Like The Shadow of a Gunman which is firmly rooted in the Irish soil, this play discusses a very serious Irish matter which is concerned with Irish Civil War. The actions are about the bloody events that are resulted from the conflict between those who accept the Free State Treaty, which stresses the joining of six counties in the north of Ireland within the British Commonwealth, and the Republicans who refuse the betrayal of their ideals in having completely independent Ireland ( Hayley; 1981, 9). In this play, O'Casey expresses the suffering of the Irish individuals during the Civil War represented in the suffering of the Boyles family. O'Casey mocks the Irish pretentious nationalism by giving us a negative picture of the Irish society looting and stealing others property. Other issues are employed such as poverty, unemployment and illiteracy. This play is therefore considered to be his masterpiece since he directs the national and universal interest toward its artistic value. The national dimension was introduced in having the play setting in Dublin. He also uses the original dialect of the Irish people which was a common feature in his plays. Yet his theme of rejection of war and its serious effect on the individual is a universal theme. The sub themes of poverty, illiteracy and unemployment are known in many countries all over the world. In other words, O'Casey is concerned with the liberation of "the individual, the race, the class" from any type of oppression and injustice. (ibid, 91)

Juno Boyle is an interesting character because she is the only active character in the play. She represents the Earth mother who manages her household and cares about her family. The problems that resulted from the war seem not to affect her, she is practical and always ready to solve any trouble that faces her family. The name Juno, as Simmons argued, suggested the angry and powerful 
wife of Jupitor, "Continually bothered by her husband's royal excesses." however the peacock "is the bird associated with Juno" (Simmons, 56). This is as far as myth is concerned, but it is worth hinting that this interpretation of the names must not to be taken into serious consideration because it is emphasized that the name has nothing to do with its mythical origins. Captain Boyle justifies the reason why his wife is called Juno:"Juno was born and Christened in June: I met her in June, we were married in June, and Johnny was born in June, so wan day I say to her, "you should ha' been called Juno" an' the name stuck to her ever since" (Act. 1, p. 65).

On the other hand, the Captain, Jack Boyle introduces the negative side of Juno; he is totally different from her in everything. He is presented in a comic way, but he is at the same time the one who contributes to the tragic end of the play. Unlike his wife who works to keep her household in a good way, as usual in a case of EARTH MOTHER he avoids work and spends his time joking with Joxer, another comic figure. Some critics discuss that tragic/comic element that has been brought in the play by the character of the Captain. It has been noted that the tragedy of the family's destruction and the death of the son are described within the farce techniques. Although we have many comic incidents in the play, all of them became of greater effects when are related to the tragic themes of the play. For instance, the Captain comic nature makes us laugh at first. His idleness, drunkenness are introduced humorously, but they carry within them tragic implications since they are going to be a considerable cause for this destruction (Hayley, 76). Kroneberger offers a definition of comedy which seems especially appropriate in this context:

Comedy appeals to the laughter, which is in part malice, in us, for comedy is concerned with human imperfection, with people's failure to measure up either to the world's or their own conception of excellence -- comedy tends to be skeptical and says in effect, "The absurdity of it, that inspite of his fine talk or noble resolutions, a man, is the mere creature of pettiness and vanity and folly --- Comedy is criticism, then, because it exposes human beings for what they are in control to what they appear to be. (Kronberger ; 1952,4 )

With regard to the other members of the family, Johnny and Mary, they are included in the political dilemma of the war. Johnny who participates in the 1916 events, and has a great participation in defending his country is presented ironically. This heroic action is mocked when Johnny has betrayed his comrade Tancred, to the English forces which causes his death. Actually, we do not know the real cause behind his treachery, yet whatever it proves to be, there is a clear implication of the rejection of the Irish-national attitude toward war. Here they civil war causes the Irish people to fight against each other. "neighbour against neighbour, friend against friend. " (Heyley, 58). Johnny suffers from the sense of guilt. He is no longer that great hero who was injured during the war events. In fact he is a self-pitying coward who expresses this fear whenever he hears a knock at the door. Actually, he can be seen as a figure representing " the maimed youth of Ireland cheated of their right to live and work sensibly by the follies of senseless heroic and Civil War" (ibid, 59). It is through this character that O'Casey introduces the passive attitude of some of the Irish people toward politics. Johnny the young Irish man who is representative of his country's youth is against the signing of the Anglo Irish treaty because of its exclusion of some of the Irish land from Ireland's rule. Perhaps his rejection of the Irish political disorder is the cause of his sense of disappointment. This tendency is emphasized when he expresses his opinion about Ireland saying "Ireland only half free 'II never be at peace." (ibid ,65).

Moreover, O'Casey's passive attitude to the Irish politics brings him round to a point that he expresses "Jingoistic" dramatists who try to introduce that image of the Irish hero who is ready to die for Ireland; O'Casey mocks this attitude in the portrait of the suffering of the characters who are involved in the dilemma. Probably, the sense of Tancred's death fitted greatly in this context. Actually, in this sense we have some of Tancred's neighbor reported that "he died a noble death an' we'll burry him like a king"; his mother who is angry for her son's death dose not interrupt him but 
when he says that "It's a sad journey we're goin' on, but God's good, an' the Republicans won't be always down", Mrs. Tancred answers with a tragic-ironic tone saying "What good is that to me now? Whether they're up or down. It won't bring me darlin' boy from the grave." (O'Casey, 79). The people's suffering was obvious, and O'Casey tries to show us that the Irish society is tired of war and is looking for peace.

This treatment was also emphasized in the final action the play when the IRA Soldiers enter the Boyles apartment and ask Johnny to come with them to be questioned about the betrayal of Tancred. Here, the hero who keeps telling the other characters about his heroic role in the Easter Rising is seen as a coward and arouses our sympathy for him. He pleads for them saying:

I won't go! Haven't I done enough for Ireland! I've lost me arm, an' me hip's destroy so that I'll never be able to walk right again! Good God, haven't I done enough for Ireland?

The young man: Boyle, no man can do enough for Ireland. (Act. 2 , p. 83)

Not only does the war affect the Boyle's family but it actually causes the Irish society as a whole to suffer from serious problems such as poverty, illiteracy and the robbing of the properties of the others.

O'Casey's treatment of poverty as presented in his plays is shown to be present on the personal and social level. Actually, O'Casey experience in Dublin enables him to notice the high-degree of poverty's influence on the life of the people. In this play poverty seems to affect the life of the individuals and their personal relationship. Poverty is introduced in two types: the financial poverty and the intellectual poverty. It seems that Ireland suffers from these two problems since they are both important for the country's welfare and prosperity.

With regard to the first type of poverty, the financial poverty is apparent in the majority of his works. With regard to this play, the Boyles live on credit in a poor apartment in Dublin. The Boyles's suffering is clearly seen when O'Casey shows how much the people are changed when they have money. In this play O'Casey shows the unexpected richness and its effect on the manner of life. The family is seen as representative of all Irish families suffering from, the bad result of poverty. Poverty is seen to change the kind of people's behavior; probably the most important example is introduced in the character of Juno. Her bitterness toward her husband is related to the lack of money; her husband is a man who spends his tome joking and drinking with his friend Joxer. It is Juno, his wife, who supports the family financially. This causes her to treat him in this bad way:"your poor wife slavin' to keep bit in your mouth an' you captain an' you only wants on the weather "(Ibid, 50). However, when they hear about the possibility of having money, they run to live a life of a high - level, they take a credit and change their old furniture.

The function of the will is of a serious effect since every member found release in it. The mother considers it as a way of getting rid of debts and ad a financial sate life. The captain considers it as a way of avoiding his wife's continuous complaint about their poor conditions, and in avoiding work which his wife wants him to have. Mary looks forward to having money and a new kind of life that the rich have. For Johnny, he hopes to change their apartment and move to another place where the police can't find him. The function of the will, the promised richness, is of great importance since the Boyle's problem has an end by the use of money, though the will proves to be unreal, the Boyles family is destroyed because their creditors come back and take their goods. So, the promised richness is the cause behind the family's destruction. this attitude can be linked with the historical background. O'Casey represents a known class of people in the Irish Gaelic Society who tends to live as rich people while they are very poor:

Irish Gaelic Society and culture was put down by the English

invaders; but Gaelic poetry in the eighteenth Century is riddled with 
contempt for the ignorant upstarts who have the power and live in the castles, while the Irish nobility and their bards must wear rags and hide in the wilderness. Captain Boyle is not just the universal lazy braggart; he is the tag-end of that tradition of supplanted nobility, of people with habits above their station (Simmons, 55).

Therefore, from this historical perceptive, Sean O'Casey seems to introduce a modern character to represent their classic role. The captain is a figure who stands for the suffering of the Irish people who dream about a sudden richness. This dream is considered as a release from the pressure that poverty has on them.

Another important thing which is directly related to poverty is unemployment; this issue is being focused on greatly. The major characters in the play are without work; for instance, the captain who is responsible for his family living is without work, he even does not care about having any kind of work. He depends on his wife, the only character who works in the family, to earn the living. Johnny, the young man, has lost his arm in the uprising war. This, of course, is a considerable cause for employers to reject him. More than once, his mother mocks him and his ideals, "you lost your principles when you lost your arm"(O'Casey, Juno and The Paycock, 1981, 65). On the other hand, Mary, who used to work, is without a job now since she was on strike with the other workers. Consequently the play in general is a protest by O'Casey on the economic situation of Ireland during the rebellion and the Civil war.

The second type of poverty that O'Casey attracts our attention to is the "intellectual poverty". O'Casey views illiteracy as another face of poverty is as serious as illiteracy. The characters are presented as illiterate because they have no money to buy books. His major characters are poor workers who try hard to earn their living. In this play, the family is nearly almost illiterate with a specific exception to Mary. Mr. Boyle is illiterate; he is not interested in education. Johnny is a soldier who is busy with the unstable political situation of Ireland; and so Mary is the only hope for her family. She is different from any other character. The stage directions said:"two forces are working in her mind-one through the circumstances of her life, pulling her back, the other through the influence of books, she has read, pushing her forward"(Ibid, 47). O'Casey shows the effect of poverty even on a character as Mary. Because of the financial reasons Mary prefers a rich lawyer over her poor lover. She is doomed in this false choice because the lawyer deserts her after her pregnancy. After the loss of her finance ' her previous lover comes to see her but because of her pregnancy he refuses her. She has lost both her lover and fiancé because of her desire to be rich. It is clear then that O'Casey is very pessimistic about Ireland's future even for the educated citizen. Gifted men and women, who are looking for better future, are troubled by their society's circumstances. Education is of no value unless individuals have a fair opportunity of a better life. Probably this is the message that O'Casey wants his audience to realize. Education can play an effective role if the country's circumstances are free from the economic and political disorder.

Finally, the last thing that O'Casey criticized in his treatment of Irish material is the looting and robbing of others' properties during the bloody events of the uprising. This type of treatment has to do with the realistic experience that O'Casey has undergone during the years of war in Dublin. In this respect O'Casey seems to be laughing at the Irish society who pretend to have a great sense of nationalism. He mocks this false heroic sense by showing a slice of the Irish society who does not care about the serious political situation that Ireland has undergone. This tendency to loot things is emphasized in many different episodes of the play. This fact raises a big question about the people's responsibility in maintaining order of their country. Irish people are shown violating order and law of their own country. The end of the play is very pessimistic: Johnny and Mary the representatives of Ireland youth are shocked by their society. They are to a great extent the real victims of the war. Johnny the handsome young man is taken by the Irish soldiers to be questioned about Tancred's death. Later his death is reported to us. Mary the hope of her family is pregnant; whereas her tenement with her daughter Mary to another place. The play ends with the speech between Joxer and 
Mr. Boyle drunken and unaware as they are in the last speech in the play; Captain Boyle and Joxer introduce very serious information which sums the theme of the play:

Wan single, Solitary tanner left out of all I borrowed.

(He lets it fall) the last of the Mohicans. The blinds is

down, Joxer, the blind is down --- The country 'll have to

steady itself. It's going to hell, where're all the chairs ---

gone to --- steady itself, Joxer. Chair 'll have to steady

themselves --- I'm tellin' you, Joxer, th' whole worl's in a

terrible state o' chassis (Act, 3, p. 101)

The last speech of Mr. Boyle has summed up the whole play. In this speech O'Casey's introduces his message "The Country 'II have to steady itself, It's going to hell". Irish uprising which is considered for other Irish writers of a great sense of pride and aspiration is 'hell' from O'Casey's perspective. In this play, he introduces "Juno" who is representative of the Earth Mother and it is only her that deserves to be the heroine of the play.

\section{$5 \quad$ The conflict between Ideals and Reality}

Like Juno and the Paycock, which depends on Irish political events Red Roses for me is based on the rail strike of 1911 in Britain and Ireland. (Maxwell, 110). Red roses for me is similar to Juno and The Paycock, in having Dublin city for its setting. This play is taken from an actual experience the Dubliners have undergone, it is about the demand that the workers call for, which is concerned with the increase of extra shining a week. The demands are not accepted and they are attacked by the English police. This confrontation causes the death of two men and the injury of hundreds of them.(ibid). This play is about the tragic death of an Irish hero, Ayamonn, during the strike, who is introduced as a man of firm principles. His beloved Sheilla does not agree with his political beliefs, which causes him to suffer. He is a very active labourer who urges the other workers to call for their rights and to organize a strike for this purpose. Toward the end of the play, the hero has to choose between his ideals of nationalism and labour and his love to Sheila. Since he is a patriot nationalist, he chooses the former sacrificing his love for the sake of his cause as well as the workers' rights.

The shilling increase for him stands for a dream of better world because it means victory of workers over their oppressors. Ayamonn is killed by police. However, after Ayamonn's death, Sheila has realized that she is mistaken in judging Ayamonn. She decides to complete what Ayamonn has begun since it is his death that inspires other worker to fight for better conditions of life.

The play's importance is in the conflict that is embodied between ideals and reality. Ayamonn's ideal world of Dublin.

The whole play is seen to be about this major character Ayamonn is his struggle to fulfill his dream. Though this romantic dream of a better life has to be stopped by the hero's death, it is his death that opens a new phase of the strike against the English employers. Hence the classification of it as a romantic tragedy is suitable here. In this play, Aymonn is considered to be the leader of the workers' strike. It seems clearly then the another slice of the Irish society will be focused on in this particular play. Unlike The Shadow of Gunman which introduces the soldier's image and importance in the Irish society, this play is concerned with the workers issue. Also, in Juno and the paycock, O'Casey reflects the effect of war on the Irish family. O'Casey's attitude was clear since he intends to offer a comprehensive picture about the different slices of the Irish introduced as a man who has possessed certain qualities in himself that qualifies him to play that heroic role. Actually, he is wellknown for his courage, bravery and his commitment to his political ideals.

It is argued that the character of Ayamonn is very close to O'Casey's real nature; both of them are revolutionary and seek to have a better life of their country. Ayammon is also similar to O'Casey in having a sensitive poetic nature. This opinion is investigated by many writers, for example Cecelia Zeiss supports this critical opinion saying that the values that are affirmed by O'Casey in his dramatic 
career are embodied in the character of Ayammon. For her, Ayammon's social vision represents an ideal world for the future and a reaffirmation of Ireland's mythic past. ( Zeiss 1984,181 ). His political principles are very close to O'Casey. He urges the people for the practical kind of action of Ireland's welfare, he asks the people to "remember [themselves] and think of what [they] can do to pull down th' banner from dusty by gunes, an fix it up in th' needs an' desires of today." (O'Casey, Red Roses for me , 198) .

However, his dream of freedom is different from that which is known by the other Irish heroes. Actually, he wants a new kind of freedom which is directly involved with truth, ":Let us bring freedom here, not with sounding brassan' thinking cymbal, but with silver trumpets blowing, with a song all men can and a heads man's axe on our shoulders "(Act. II, p. 169).

So, this kind of freedom which Ayamonn calls for, stresses the particular effort of all Irish workers. Yet, his dream is never fulfilled because the bounds the society has on him. Ayamonn sees in Sheila the mythical figure of Cathleen Nihoulihan which stands for Ireland oppressed and rich in hope (Maxwell, 110). The hero's poetic nature is revealed when he wrote a song to Sheila glorifying his sweet heart as Cathleen, "A sober black shawl hides her body entirely, Touch'd by Th' sun and th' salt spray of the sea; But down in th 'Darkness a slim hand, so lovely, carries a rich bunch of red roses for me." (Act.1, p.19)

The " Shawled" figure is Cathleen ni Houllihan whom Ayamonn sees in the figure of Sheila, yet Sheila refuses to be seen as Cathleen and favors to be far from any political vision :"you think more of your poor oul' Ireland your songs, and your workers' union than you think of [Me]". He tells her, "you're part of vision, bonnie rose, delectable and red" (O'Casey Red Roses for me, 144).

Actually, many critics are troubled by the identification of the mythic figure who is representative of Ireland's hope with " a ragged woman of the slums rather that with the patriots" (Maxwell, 115); this may be attributed to O'Casey refusal to accept the heroism of 1916 events. He wants to mock this mythical Irish heroine because their faith in common humanity ... Their allegiance to Cathleen ni Houlihan greater than their Cathleen faith" (Ibid ,245). This attitude of making the Irish heroes is clearly seen in this play because what O'Casey is after is the real feeling of the Irish people. He introduces the other face of the Irish society whereas; the other writers tend to produce the bright image of Ireland.

However, the failure of the two lovers to reach any kind of agreement is in itself a reflection of the social forces that work everywhere in Ireland. In this case poverty plays a serious role and prevents the fulfillment even of personal wishes. (Simmons,55). Ayamonn in his confrontation with Sheila has to choose between her and his ideals, "you will either have to make good or --- lose me" (O'Casey, Red Roses for me , 172). Of course because his national beliefs are stronger that any power he decides to translate his dream into reality and leads the strike of the railway workers.

The workers join Ayamonn and organize the strike to have their rights; their strike is unsuccessful and the police attack them. However, during this bloody strike, Aymonn is killed. O'casey uses Irish myth to increase the effect of the hero's death. He likens Ayamonn to Brian Boru who is one of the Irish mightiest kings (Ayling, 151). This tells us that the Irish heroic myths are still alive in the mind of the modern Irish man:Well, we've got Guinness's Brewery still, givin' us a needy glimpse of a praisin' the puttin' of Brian Boru's golden harp on every black prother bottle" (Act.3, p. 187).

Ayamonn seems to have a royal characteristic of the Irish grand heroes. He represents the nationalist who has a faithful commitment to his country. He sacrifices and succeeds in making the workers demand their rights. His death is heroic though some of his enemies consider his end as a mean death.

His death is also glorified by another comparison between him and the legendary Dunn-Bo. O'Casey draws an Irish legend to make the audience fell that Ayamonn's death is as heroic as the Irish legendary heroes:

Things are but dimly seen, save the silver spire and the

Crimson pillar in the distance, and Ayamonn's head set in

A Streak sunlight, looking like the several head of Dunn- Bo 
Speaking out of the darkness. (Act.3,p.198).

The legend of Dunn-Bo was simply about a famous warrior who is fighting with the king of Erin; he is killed and his head is put on a pillar. Although his head is cut, he keeps singing after his death. However, Ayamonn's head dose not sings but it is his death that inspires the other workers to go on their strike. His head is considered as a symbol of sacrifice. (Ibid) .

However, Ayamonn's sweetheart, Sheila, recognizes that she is mistaken in judging Ayamonn. It is after Ayamonn's death that she acknowledges the role she has previously rejected ad at this moment of recognition she urges the workers to go on in their heroic struggle. She is considered as Cathleen ni Houlihan who stands for Ireland's hope.

\section{Conclusion}

In Dublin Trilogy, O'Casey succeeds in depicting the suffering of the Irish workers in Dublin Slums and transforming it into dramatic masterpieces. Actually his plays contain a great deal of social criticism of Ireland after the end of the English colonization. This fact is what makes O'Casey plays different from other writers. To sum, in The Shadow of a Gunman, Juno and the paycock, Red Roses for me, O'Casey does not introduce any myth. On the contrary, he demythologizes the Irish themes by presenting the social ,economic and political curses of the post-colonial Irish society in general and Dublin slums .in particular, such as poverty, unemployment, and religious/ political hypocrisy.

\section{References}

[1] Ayling, Ronald.( 1991).Seven Plays by Sean O'Casey. London: Macmillan.

[2] Benson, Eugene.( 1982.). J.M (.Synge Dublin: Gill and Macmillan.

[3] Casey, j. Daniel .( 1994.)."An Aran Requiem: Setting in Riders to the sea" in Critical Essays on John Millington Synge. New York: Maxwell and Macmillan.

[4] Corbett, Mary Jean .( 2000). Allegories of Union in Irish and English Writing, 1790-1870: Politics, History, and the Family from Edgeworth and to Arnold. New York: Cup.

[5] Corkery, Daniel (1931)..Synge and Anglo-Irish Literature. Cork; cork university press

[6] Darin, Doris. (1946.).Sean O'Casey .New York: Frederic Ungar Publishing Co(1994.)."Synge's poetic use of language". In Critical Essays on John Millington Synge. New York: Maxwell and Macmillan.pp.80-95.

[7] Eliot, T. S. Selected Essays". (1953). London. Faber and Faber Limited.

[8] Fermor, Una Ellis .(1977).The Irish dramatic movement, London; Methuen.

[9] Green, H. David . (1994)."J.M. Synge" A reappraisal" In Critical Essays on John Millington Synge, New York: Maxwell and Macmillan.

[10] Gregory, Augusta Lady. (1972). Our Irish Theatre .New York: Colinsmythe Ltd.

[11] Grene, Nicholas . (2000) The Politics of Irish Drama: Plays in Context from Boucicault to Friel. New York: cup.

[12] -------- (1975).Synge: A Critical Study of the plays. London: Macmillan.

[13] Hayles, Barbara (1981). Sean O'Casey's Juno and the Paycock, London: Longman York Press.

[14] Hochman, Stanley(ed.) (1984). MC Draw-hill encyclopedia of world drama . USA; MC Draw-Hill Book.

[15] Jacobs, Gertrude . (1962).Dictionary of Mythology, Folklore and Symbol.

[16] King, Mary C.. .(1985) The Drama of J.M. Synge. London: Fourth estate.

[17] Kitishat, Amal Riyadh. (2012). " Colonialism and the recreation of identity: The Irish Theatre as case study." Journal of Language and Culture. Vol. 3(5). pp. 83-86

[18] Kroonenberg, Louis .(1952.). The Thread of Laughter. New York: Hill \& Wang. 
[19] Krause, David .(1982). The Profane Book of Irish Comedy. Ithaca: Cornell Un. Press.

[20] ---(1984). . "The Risen O'Casey: Some Marxist and Irish Ironies" In O'Casey Annual. 3,pp. ,pp. 43-62.

[21] Levites, Ben. (2002).The Theatre of Nation: Irish Drama and Cultural Nationalism, 18901916, New York: cup.

[22] Maroldo, J. William (1983). "Insurrection as Enthymeme in O'Casey Dublin Trilogy" O'Casey Annual 2.

[23] D.E. S. Maxwell, (1984). A Critical History of Modern Irish Drama 1891-1984 Cambridge: Cambridge Un. Press,.

[24] D.E.S Maxwell, (1984). .A critical history of modern Irish drama . 1891-1980. Cambridge ; Cambridge university press.

[25] O'Casey, Sean . (1932). The Shadow of a Gunman. New York and London: Samuel French.

[26] ----..(1948). Red Roses for Me. London: Macmillan,1948.

[27] ------..(1956). The Power of Laughter. Westport: Braziller,1956.

[28] ------. (1961). The drums of Father Ned . London and York: Macmillan.

[29] Price, Alan, ed. (1961). .Collected Works of J.M. Synge. Vol. IV, London: Macmillan.

[30] Rodgers. (1959). Rev. of David H. Green and Edward, M. Stephens. J.M. Synge. New York: Macmillan.

[31] Rollins, G.R. Ronal . ( 1985). "The Drums of Father Ned: Celtic Heroes and Harps and the Merry Mummers of Modern Ireland" In O'Casey Annual.

[32] Saddle Myer . ( 1971). Ann Letters to Molly: John Millington Synge to Maire O'Neill. Massachusetts: The Harvard University Press.

[33] Schrank , Bernice . ( 1977).”Naturalism of O'Casey Early plant" in The Sean O'Casey Review.4(1),pp. 43-62.

[34] ------ ( 1977). "The Naturalism of O'Casey Early plant" in The Sean O'Casey Review .vol. 4(1).,pp. 43-62, Fall.

[35] ------( 1978). "'You Needn't Say No More': Language and Problems of Communication in Sean O'Casey's 'The Shadow of a Gunman'", Irish University Review, 8 (1), , 1978, pp. 23 38 ; a

[36] ------.( 1985). ." 'There's Nothin' Derogatory In th' Use o' th' Word': A Study in the Use or Language in The Plough and the Stars". Irish University Review, 15), p. 169.

[37] Simmons, James ( 1988)..Sean O’Casey . London ; Macmillan, 1988 .

[38] Skelton, Robin and Ann Saddlemyerleds. (1969). The World of W.B. Yeats. New York: U. Washington.

[39] W.B. Yeats, ( 1974). Essays and Introductions. London: Macmillan. 